\title{
Promotion and Utilization of Niche Foods for Food and Nutrition Security
}

\author{
Waswa J. ${ }^{1, *}$, Ngugi L.W. ${ }^{1}$, Asiko L.A. ${ }^{1}$, Ambani R.S. ${ }^{2}$ \\ ${ }^{1}$ Department of Food Science and Nutrition, Karatina University, Kenya \\ ${ }^{2}$ Department of Agriculture, Bukura Agricultural College, Kenya
}

Copyright $\bigcirc 2016$ by authors, all rights reserved. Authors agree that this article remains permanently open access under the terms of the Creative Commons Attribution License 4.0 international License.

\begin{abstract}
Food and nutrition security exist when there is availability and accessibility of food in terms of quality and quantity. Each environment has foods adapted to the region and culturally acceptable to the inhabitants. Niche foods have in the recent past been neglected yet they have a great potential of solving the food and nutrition security issues among communities. This paper takes particular interest in traditional vegetables and insects that were popularly used in the past but are being viewed by the current generation as 'overtaken by time' hence being neglected. African Leafy Vegetables like black night shade, amaranth, cowpeas, and many others are quite nutritious apart from possessing some medicinal qualities. Insects like grasshoppers, termites, caterpillars are a good source of protein of high biological value. Food Agriculture Organization (FAO) has in the recent passed advocated for the utilization of insects as a way of combating food insecurity in the world. The purpose of this paper was to review the importance of niche foods as used in parts of the world with an aim of promoting their use in Kenya.
\end{abstract}

Keywords Food Security, Nutrition Security, Niche Foods, Insects, African Leafy Vegetables

\section{Introduction}

Retaining the native food systems in developing countries which contain immense agricultural biodiversity is one sustainable way of ensuring food and nutrition security for poor populations [1]. In Sub-Saharan Africa, this biodiversity contributes greatly to food and livelihood security. However, the current technological changes which come together with socio economic changes are contributing to changes in dietary patterns and food habits. These changes contribute immensely to the current epidemiological trends in the region. Sub-Saharan Africa continues to be overburdened by nutritional and diet related health problems, most of which can be attributed to insufficient micronutrient intake and the consumption of cheap, calorie-dense staple foods (which have recently gained popularity) leading to increased incidences of obesity and other diet-related non-communicable diseases [2].

Traditional foods are often under-utilized and are therefore threat ended with extinction. If niche foods have to be promoted sustainably then, the knowledge of traditional food should be encouraged. Deliberate efforts should therefore be made to develop and promote these foods to reduce the loss of bio-diversity in the regions for improved nutritional status [3].

\section{Insect Consumption as Food}

One of the ways to address food and nutrition security is through insect farming. Insects are everywhere, they reproduce quickly, and they have high growth and feed conversion rates and a low environmental footmark over their entire life cycle. Insects have been used as food in many parts of Africa, and form part of traditional delicacies [4]. Insects have high protein, fat and minerals content. These nutrients' content varies with the type of insect and body part. They are cheap to since some can be reared on waste streams like food waste. Moreover, they can be utilized in many forms; they can be eaten whole or ground into a powder or paste, and incorporated into other foods. The use of insects on a large scale as a feed ingredient is technically feasible, however, it has not been given focus. Majority of insect collection occurs through wild gathering. Modern technology combined with valuable traditional knowledge and food culture can contribute to innovation and the scaling up of mass-rearing technologies. Farming insects as mini livestock offers great opportunities to increase supply without compromising wild insect populations and without damaging the ecosystems [5].

A consumption of insects has been misconceived as a poor man's delicacy in times of hunger. However, in most 
instances where they are a staple in local diets, insects are consumed because of their taste, and not because there are no other food sources available. Certain insect species, such as termites in Western, Nyanza and parts of the Rift valley regions of Kenya attract high selling and are hailed as delicacies by all social classes.

In many parts of the world where insect eating has been a common element of traditional culture, the practice is declining due to modernization that has changed people's attitudes towards the food. In these areas, reviving the tradition of eating insects has significant potential to improve rural livelihoods, enhance nutrition and contribute to sustainable management of insect habitats. This will not only reduce of hunger, but could contribute to revitalizing traditional cultures, instilling a sense of connection with nature and fostering a better understanding of the role of humans in the natural world[5].

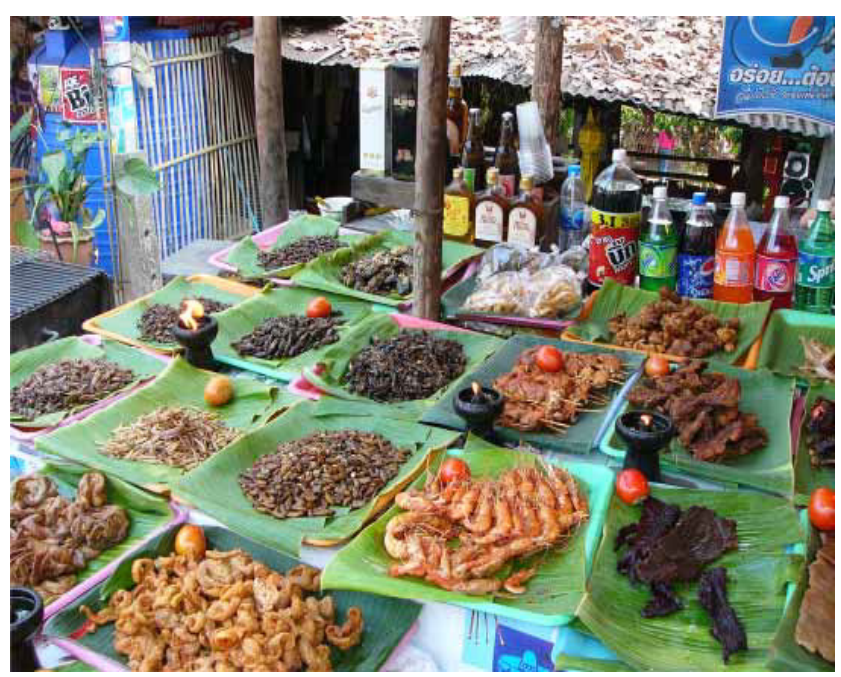

Source [6]

Figure 1. Insects on sale alongside other delicacies (northern Thailand)
Table 1. Number of edible insect species reported in the world

\begin{tabular}{|c|c|c|}
\hline Order Common & English name & Number of species \\
\hline Anoplura & Lice & 3 \\
\hline Coleoptera & Beetles & 468 \\
\hline Diptera & Flies, mosquitoes & 34 \\
\hline Ephemeroptera & Mayflies & 19 \\
\hline Hemiptera & True bugs & 102 \\
\hline Homoptera & $\begin{array}{c}\text { Cicadas, leafhoppers, } \\
\text { mealybugs }\end{array}$ & 78 \\
\hline Hymenoptera & Ants, bees, wasps & 351 \\
\hline Isoptera & Termites & 61 \\
\hline Lepidoptera & $\begin{array}{c}\text { Butterflies, moths } \\
\text { (silkworms) }\end{array}$ & 253 \\
\hline Neuroptera & Dobson flies & 5 \\
\hline Odonata & Dragonflies & 29 \\
\hline Orthoptera & $\begin{array}{c}\text { Grasshoppers, } \\
\text { cockroaches, crickets }\end{array}$ & 267 \\
\hline Thysanura & Silverfish & 1 \\
\hline Trichoptera & Caddis flies & 10 \\
\hline \multicolumn{2}{|c|}{ Total } & 1681 \\
\hline
\end{tabular}

Source: [7]

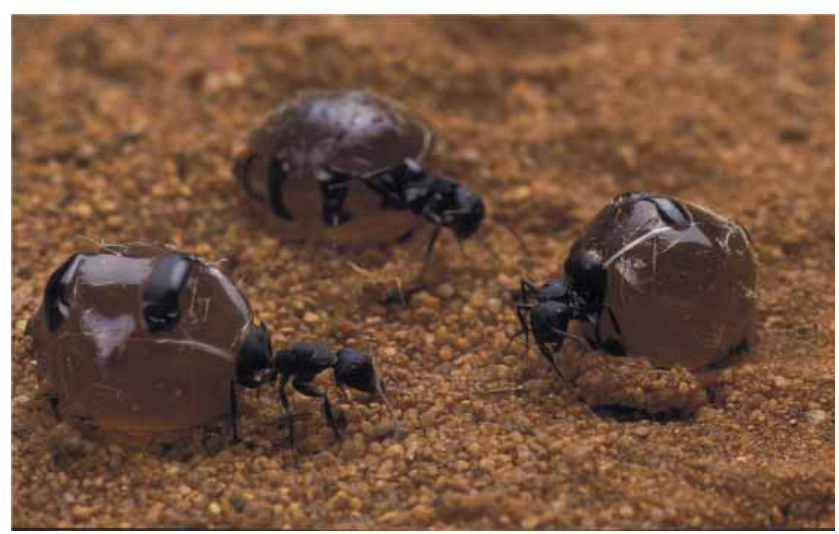

Figure 2. Honey ants in Australia (source : [6] )

Table 2. Common edible insects in Kenya

\begin{tabular}{|c|c|c|c|c|}
\hline Common name & Scientific name & Kiswahili & Kikuyu & Luo \\
\hline Desert locust & Schistocercagregaria & N/A & Gitono/ gitarariki & Bonyo \\
\hline Longhorn grasshopper & Ruspoliadifferens & Senene & Ndahi & Senene \\
\hline Grasshopper & R. Nitidula & Senene & Ndahi & Senene \\
\hline Two-spotted cricket & Gryllusbimaculatus & Nyenje & Ngiria & Onjiri \\
\hline House cricket & Achetadomesticus & Nyenje & Ngiria & Onjiri \\
\hline Termite & Macrotermesbellicosus & Kumbikumbi & Nguya & Ng'wenAgoro \\
\hline Termite & Macrotermessubhyalinus & Kumbikumbi & Nguya & Ng'wSisi \\
\hline Honey bee & Apismellifera & Nyuki & Njuki & Kich \\
\hline Black ant & Carebaravidua & N/A & Thigiriri & Onyoso \\
\hline Moth & Buneaalcinoe & Nondo & Kihuruta & N/A \\
\hline Black soldier fly (only Feed) & Hermetiaillucens & N/A & Kigunyu/wakaguku & Luang'ni \\
\hline
\end{tabular}

source [8] 


\section{The Termite}

Scientific name - Macrotermesspp

Local name - Luhya - Chiswa, Luo - Ng'wen Agoro

Swahili name - Kumbikumbi

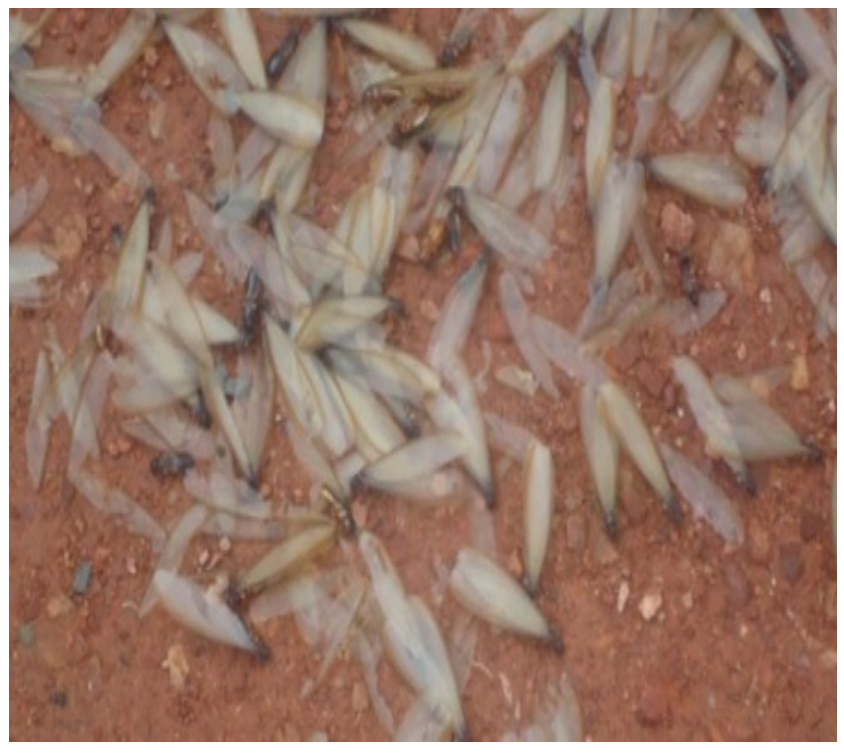

Figure 3. Termites after hervesting in western Kenya

In Western Kenya, termites form part of the delicacies when they are in season. They are either consumed rawor fried and eaten them with ugali or plain. They are also an economic activity since 1 kilo gram of the dried ones would go at between Ksh 500-1000. This forms a cheap source of proteins for the poor masses who harvest them. However, there importance has not been given more emphasis[9]

\section{Harvesting of Different Termite Species in Western Kenya}

Normally, people erect a small tent (siswa) which they cover with blankets leaving an opening that leads to a special hole dug at the opening where termites will slide into then they are collected. The special hole is called 'efubo' which has banana leaves inside and at the entrance where termites slide and fall into the hole. There are different species that come out at different seasons of the year making the delicacy available in all seasons[9].

Chiswachisisi (local name) which are blackish in colour and the smallest in size. These ones are mostly seen during the rainy season from about $2 \mathrm{pm}$ to $4 \mathrm{pm}$ in the months of September to December. Early in the morning women and children collect three shot sticks which are used to invite the termites. Sticks are beaten, this is to sound like rain and because termites emerge when it begins to rain, they all come trooping out during the day. Another group of termites is called Chinunda which are brownish in colour and mostly comes out from $5 \mathrm{pm}$ in the evening common in the months of December to February [9]

There is also another group called Kamabuli that are common in the months of December to February that appear late in the evening from $6 \mathrm{pm}$ to $7 \mathrm{pm}$. They are blackish in colour and usually take a very short time after they start coming out. Chimome are blackish in colour and normally come out when it is raining, commonly in the months of June to October. Chindawa termites are blackish in colour and also appear when it is raining, are common in the months of April-May. Kamaresi are dark brown in colour, the biggest in size and normally appear at night. This season as from April to June is for Kamaresi that people capture at night. They are attracted to the light and that is how Bamasaaba people get them using light. Kamaswakhe are blackish in colour and also appear at night. Chingalabuwetermite species are common in the months of September to November and are brownish in colour. Kamaachichi are common in April to May and their appearance resembles wasps and they are blackish in colour. They appear mostly at around 9am to $11 \mathrm{am}$. Bikeke are blackish in colour and are associated with some species of termites [9]

\section{Nutritional Value of Insects}

A diverse diet, with a balanced contribution from plant and animal-source foods, is the best way of securing nutrient security. In food insecure populations, diets often lack sufficient amounts of animal source foods like meat, fish, milk and eggs to support good nutrition and health [8]. Micronutrient deficiencies are widespread and are a cause of serious public health problems.

Vitamin $B_{12}$ is derived exclusively from animal-source or fermented foods, while critical micronutrients such as vitamin $\mathrm{A}$, iron and zinc exist in more bio available forms in animal-source foods compared to plant foods. Animal-source foods also provide a higher proportion of essential amino acids as well as the essential n-3 fatty acids[8]. Insects contain most nutrients present in animal food sources and should be consumed to utilize the advantage.

\section{African Leafy Vegetables}

Indigenous fruits and vegetables were consumed by the rural populations for nutrition and food security. The hidden potential of indigenous fruits and vegetables needs to be exploited as they could play a crucial role in solving malnutrition, food insecurity and poverty challenges facing Africa[10]. There exists rich diversity of African indigenous vegetables which when consumed they contribute to good nutrition and health [11]. African leafy vegetables are now a preferred choice by most people in Kenya[12]. A study in Nairobi revealed that a significant proportion (34\%) of the people living in urban and peri-urban Nairobi consume indigenous leafy vegetables. The vegetables are liked because of the nutritional and medicinal value attached. The 
major constraints to consumption of indigenous leafy vegetables were the cost, lack of time and knowledge in food preparation. These constraints pose a challenge to promotion of production, utilization (preparation and processing) and commercialization of indigenous leafy vegetables[13]. Common indigenous vegetables consumed in Kenya are cowpea leaves (Kunde),Jute (mrenda), pumpkin leaves (Seveve, malenge leaves) Amaranthus (Terere) Bacella alba (Nderema)spider plant (Saget, saga), Black night shade (Managu, osuga), Crotolaria (Mitoo).[11].

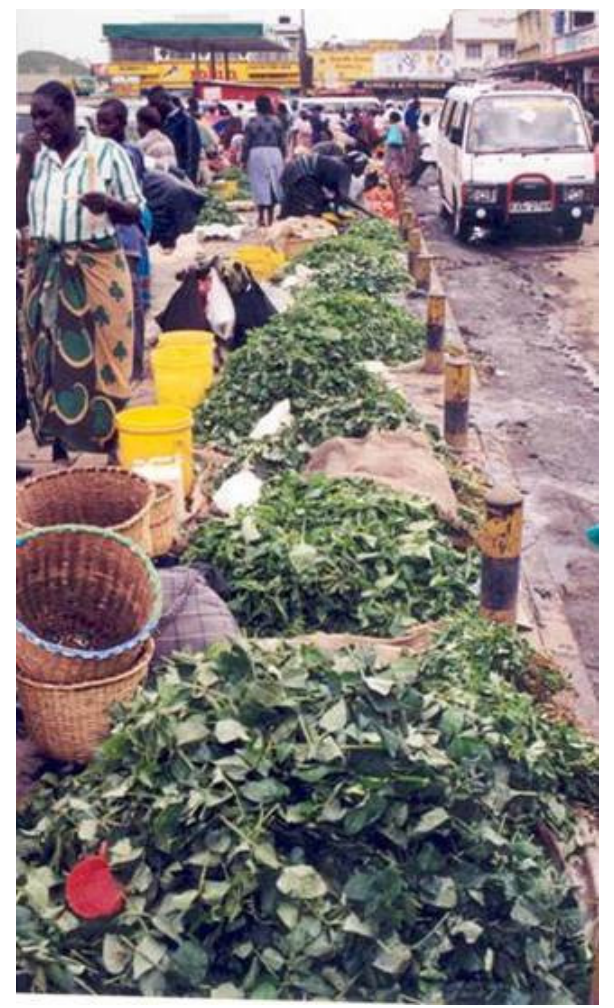

Figure 4. Africanleafy vegetable on the market for sale (source :Biodiversity international)

\section{Nutritive Value and Health Benefits of African Leafy Vegetables}

With reference to food security and nutrition, indigenous vegetables are rich in vitamins, minerals, proteins and anti-oxidants. They improve palatability and add variety to diets, especially those who consume. They are particularly valuable sources of food during emergency periods such as occur during flood, famine, drought and war[10]. A nutritional evaluation of indigenous vegetables in two sites in Kenya considered that the nutritional contribution of cooked and uncooked vegetables was enormous $[10,14]$.

African indigenous fruits and vegetables have medicinal properties and health benefits. Spider plant (Cleome gynandra), for example, has been reported to relieve constipation and facilitate child birth [15], while African nightshade (Solanumscabrum) has been documented to cure stomach ache [16]. They are also known to contain substantial amounts of antioxidants that scavenge for and bind to harmful radicals, which have been linked to ailments such as cancer, diabetes and cardiovascular diseases.

\section{Conclusion and Recommendations}

Niche foods have a high potential of improving food and nutrition security and at the same time as an economic activity hence an impetus to the production and consumption is necessary.

Most edible insects in Kenya are harvested directly from nature by traps or hand gathering. Research into sustainable technologies of harvesting should be exploited through better understanding of their biology, ecology and their ecosystem functions.

Improved production technologies are required to increase yields of Niche foods. Appropriate management, preservation and processing procedures for the priority species of insects and vegetables are required.

\section{REFERENCES}

[1] Padulosi, S., Bhag Mal, S., Bala Ravi, J., Gowda, K.T.K., Gowda, G., Shanthakumar, N., Dutta, M. (2009) 'Food security and climate change: role of plant genetic resources of minor millets', Indian J Plant Genet, Resources, vol 22, no 1, pp.1-16.

[2] Mendez, M.A., Monteiro, C.A., Popkin, B.M. (2005) 'Overweight exceeds underweight among women in most developing countries', Am J ClinNutr, vol 81, pp.714-721

[3] Omo, 2003.

[4] Kelemu, S., Niassy, B., Torto, B., Fiaboe, K., Affognon, H., Tonnang, H., Maniania, N.K., Ekesi, S. (2015). African edible insects for food and feed: inventory, diversity, commonalities and contribution to food security. Journal for Insects as Food and Feed 1(2), pp. 103-119.

[5] FAO (2015) The contribution of insects to food security, livelihoods and the environment. Rome. FAO.

[6] FAO (2010) Forest insects as food: humans bite back Proceedings of a workshop on Asia-Pacific resources and their potential for development 19-21 February 2008, Chiang Mai, Thailand

[7] Ramos-Elorduy (2005)

[8] GREEiNSECT (2016) Technical brief \#1: Insects as food and feed in Kenya - past, current and future perspectives. International Conference on Legislation and Policy on the Use of Insect as Food and Feed in East Africa

[9] Kitale Museum, 2015

[10] Abukutsa, M.O.O., Kavagi, P., Amoke, P. and Habwe, F.O. (2010). Iron and protein content of priority African indigenous vegetables in the Lake Victoria Basin. Journal of Agricultural Science and Technology 2(1): 67-69. 
[11] Maundu P, Judith Kimiywe, Maryam Mbumi, I. F. Smith, T. Johns,P.B. Eyzaguirre. (2007) Nutrition and Indigenous Vegetables in Urban and Peri-Urban Agriculture in Kenya. Bioversity International Shiungu \& Oniang'o.

[12] Kimiywe J, Judith Waudo ,Dorcus Mbitheland Patrick Maundu (2007). Utilization and Medicinal Value of Indigenous Leafy Vegetables Consumed in Urban and Peri-Urban Nairobi , African Journal of Food, Agriculture, Nutrition and Development vol 7 \#4.

[13] Habwe, F., Walingo, M. and Abukutsa, M. (2010). Copper and ascorbic acid content of cooked African indigenous vegetables. Poster: International Research on Food Security, Natural Resource Management and Rural Development. Tropentag, Zurich, Switzerland. http://www.tropentag.de/20 10/proceedings/node63.html

[14] Heever, E. van den and Venter, S.L. (2007). Nutritional and medicinal properties of Cleome gynandra. Acta Horticulturae 752: 127-130.

[15] Adesina, S.K. and Gbile, Z.O. (1984). Steroidal constituents of Solanum scabrum subsp. nigericum. Fitoterapia 55 (6): 362-363. 